\title{
Penentuan Nilai Jarak Aman Sumber Tidak Bergerak: Skenario Kebakaran dan Ledakan pada SPBU dan SPPBE di Sekitar Tapak RDE
}

\author{
Dedy Priambodo* \\ Pusat Kajian Sistem Energi Nuklir, Jl. Kuningan Barat, Mampang Prapatan, Jakarta, Indonesia
}

\begin{tabular}{l}
\hline INFORMASI ARTIKEL \\
\hline Riwayat Artikel: \\
Diterima: \\
23 Mei 2018 \\
Diterima dalam bentuk revisi: \\
10 Juli 2018 \\
Disetujui: \\
13 Agustus 2018
\end{tabular}

Kata kunci:

SDV

RDE

Puspiptek

ALOHA

SPBU

SPPBE

\begin{abstract}
ABSTRAK
PENENTUAN NILAI JARAK AMAN SUMBER TIDAK BERGERAK: SKENARIO KEBAKARAN DAN LEDAKAN PADA SPBU DAN SPPBE DI SEKITAR TAPAK RDE. Nilai jarak aman (Screening Distance Value, SDV) untuk tiap-tiap jenis sumber bahaya harus ditentukan menggunakan pendekatan konservatif sehingga pengaruh kejadian interaksi yang berada di luar jarak ini tidak perlu diperhitungkan lebih lanjut. Dari pengamatan, sumber tidak bergerak yang paling banyak berada di sekitar tapak adalah Stasiun Pengisian Bahan Bakar Umum (SPBU) dan Stasiun Pengangkutan dan Pengisian Bulk Elpiji (SPPBE). Oleh karena itu, penelitian ini bertujuan untuk menentukan SDV dari SPBU dan SPPBE untuk skenario ledakan dan kebakaran dengan lokasi studi di sekitar tapak Reaktor Daya Eksperimental (RDE), Puspiptek Serpong. Studi ini menggunkan Areal Location Of Hazardous Atmospheres (ALOHA) untuk mensimulasikan zona ancaman ledakan dan kebakaran dari substansi Bensin dan LPG. Simulasi ini melibatkan ledakan dan kebakaran iso-oktana di SPBU dan butane di SPPBE untuk menganalisis zona ancaman dari skenario kecelakaan. Diketahui bahwa SDV sangat tergantung dari jenis, maupun kapasitas material berbahaya, skenario kecelakaan serta kondisi atmosfer pada sumber bahaya tersebut. Dari penelitian ini, diketahui pula suatu sumber bahaya bisa mempunyai SDV lebih dari satu nilai. SDV SPBU berkapasitas 170.000 liter untuk skenario kebakaran $976 \mathrm{~m}$ dan $1.200 \mathrm{~m}$, sedangkan untuk skenario ledakan adalah $958 \mathrm{~m}$ dan $1.200 \mathrm{~m}$. SDV SPPBE berkapasitas $25.000 \mathrm{~kg}$ untuk skenario kebakaran $445 \mathrm{~m}$ dan $565 \mathrm{~m}$, sedangkan untuk skenario ledakan adalah $430 \mathrm{~m}$ dan $573 \mathrm{~m}$. Sementara SDV SPPBE berkapasitas $100.000 \mathrm{~kg}$ untuk skenario kebakaran $913 \mathrm{~m}$ dan $1.100 \mathrm{~m}$, sedangkan untuk skenario ledakan adalah $758 \mathrm{~m}$ dan $1.100 \mathrm{~m}$. Studi ini dapat memberikan alternatif penentuan nilai SDV pada studi dan evaluasi tapak reaktor nuklir.
\end{abstract}

\begin{abstract}
DETERMINATION OF SAFE DISTANCE VALUES OF STATIONARY SOURCES: CASE STUDIES OF FIRE AND EXPLOSION SCENARIOS AT GAS STATIONS AND LPG STATION AROUND THE RDE SITE. The Screening Distance Value, SDV for each type of hazard source must be determined using a conservative approach so that the influence of the interactions event that are beyond this distance will be ignored. From observations, the most immovable sources around the site are the Petrol station (SPBU) and the LPG Station (SPPBE). Therefore, the objective of this study is to determine the SDV of SPBU and SPPBE for explosion and fire scenarios at the the Experimental Power Reactor site (RDE), Serpong Puspiptek. In this study, the Area Location of Hazardous Atmospheres (ALOHA) software was chosen to simulate the threat zone of explosion and fire from the substances of Gasoline and LPG. This simulation involves explosions and fires of iso-octane at gas stations and butane in SPPBE to analyze threat zones from accident scenarios. It is known that SDV is very dependent on the type and capacity of hazardous materials, accident scenarios and atmospheric conditions on the source of the hazard. From this study, also known a source of danger can have SDV of more than one value. SDV gas stations with a capacity of 170,000 liters for fire scenarios are $976 \mathrm{~m}$ and 1,200 $\mathrm{m}$, while for explosion scenarios are $958 \mathrm{~m}$ and $1,200 \mathrm{~m}$. SDV SPPBE with a capacity of 25,000 $\mathrm{kg}$ for the fire scenario are $445 \mathrm{~m}$ and $565 \mathrm{~m}$, while for the explosion scenario are $430 \mathrm{~m}$ and $573 \mathrm{~m}$. While SDV SPPBE has a capacity of $100,000 \mathrm{~kg}$ for the fire scenario are $913 \mathrm{~m}$ and $1,100 \mathrm{~m}$, while for the explosion scenario are $758 \mathrm{~m}$ and $1,100 \mathrm{~m}$. This study can provide an alternative determination of SDV for nuclear reactor site study and evaluation.

Keywords: SDV, RDE, Puspiptek, ALOHA, SPBU, SPPBE
\end{abstract}

(C) 2018 Jurnal Pengembangan Energi Nuklir. All rights reserved

\section{PENDAHULUAN}

Screening Distance Value, SDV atau nilai jarak aman diartikan sebagai jarak maksimum sumber bahaya dengan tapak yang mana skenario kecelakaan masih bisa membahayakan tapak[1]. SDV untuk tiap-tiap jenis sumber bahaya harus ditentukan menggunakan pendekatan konservatif sehingga pengaruh kejadian interaksi yang berada di luar jarak ini tidak perlu 
diperhitungkan lebih lanjut. Penentuan SDV harus memperhitungkan keparahan dan luas cakupan kejadian. Untuk kejadian awal yang dipertimbangkan, tidak perlu dilakukan tindakan lebih lanjut apabila tapak berada di luar SDV[2]. Telah dilakukan penelitian mengenai SDV yang sebagian besar terkait aspek kegunungapian dan kejadian akibat ulah manusia (KAUM).

Dalam aspek kegunungapian, McBirney dkk dalam kajiaannya tentang bahaya kegunungapian terhadap calon tapak Muria menggunakan SDV dari IAEA dan studi dari peneliti sebelumnya terkait kegunungapian dan kegempaan[1]. Hal serupa dilakukan Wibowo dkk dalam kajian awal bahaya vulkanologi di calon tapak Bangka. Wibowo menentukan SDV berdasar katalog vulkanologi di sekitar Bangka[3]. Penentuan SDV berdasarkan perhitungan numerik dilakukan oleh Volentik dkk dalam kajian bahaya vulkanik pada tapak PLTN Bataan. Dalam kajiannya Volentik dkk melakukan simulasi terhadap semua kejadian terkait vulkanologi sehingga didapat SDV untuk masing-masing kejadian tersebut [4].

Sedangkan dalam aspek KAUM, Yarianto dkk menentukan SDV untuk Bandar udara dengan perhitungan yang dikaitkan dengan frekuensi penerbangan di bandar udara tersebut[5]. Dalam kajian lain untuk aspek KAUM yang terkait dengan kecelakaan pada instalasi Stasiun Pengisian Bahan Bakar Umum (SPBU) dan Stasiun Pengangkutan dan Pengisian Bulk Elpiji (SPPBE), Mellawati dkk menentukan SDV untuk SPBU dan SPPBE bernilai sama dan dengan mengambil nilai dari pengalaman negara lain dalam evaluasi tapak[6-9]. Hal yang sama dilakukan oleh S. Alimah dalam studinya terkait potensi bahaya ledakan SPPBE di sekitar tapak RDE[10].

Dari paparan di atas dapat diketahui bahwa penelitian yang berkaitan dengan penggunaan nilai SDV untuk aspek KAUM khususnya untuk skenario kecelakaan pada SPBU dan SPPBE telah banyak dilakukan. Namun demikian, para peneliti hanya menggunakan nilai SDV dari referensi IAEA sebesar $5 \mathrm{~km}$ untuk skenario kebakaran dan ledakan dari sumber disekitar tapak[8,10]. Penggunaan SDV tersebut hanya melihat skenario kecelakaan tanpa melihat asal sumber kecelakaan tersebut berasal seperti jenis bahan yang terbakar/meledak, kondisi penyimpanannya, serta kondisi lingkungan tempat kecelakaan terjadi.

Dengan penetapan nilai SDV hanya berdasarkan referensi IAEA tersebut dapat berdampak pada kemungkinan luas area studi yang terlalu luas atau bahkan sebaliknya terlalu sempit. Area studi yang terlalu luas akan mengakibatkan penggunaan sumberdaya yang berlebihan dari seharusnya, sedangkan area studi yang terlalu sempit akan mengakibatkan hasil studi yang tidak akurat. Dengan pertimbangan spesifikasi bahan, tipe penyimpanan pada SPBU dan SPPBE serta kondisi atmosfer yang sudah terdefinisi dengan jelas pada sumber tidak bergerak di sekitar tapak maka penentuan SDV dengan cara menghitung skenario kecelakaan terparah berdasarkan kondisi-kondisi tersebut menjadi lebih tepat. Untuk itu penelitian ini bertujuan mendapatkan SDV untuk SPBU dan SPPBE yang umumnya merupakan sumber tidak bergerak yang paling banyak berada di sekitar tapak. Pada penelitian ini hanya difokuskan pada skenario ledakan dan kebakaran pada SPBU dan SPPBE.

Penelitian ini dapat memberikan alternatif penentuan SDV dengan mempertimbangkan karakteristik sumber serta memperhitungkan skenario kecelakaan, keparahan dan cakupannya.

\section{METODE}

\subsection{Lokasi Penelitian}

Lokasi Penelitian dilakukan di daerah sekitar tapak Reaktor Daya Eksperimental (RDE) di Puspiptek Serpong. Titik pusat tapak reaktor berada di koordinat $6^{\circ} 21^{\prime} 26^{\prime \prime}$ LS $106^{\circ}$ 39' 37" BT. Penelitian dimulai dengan pengumpulan data primer di lapangan untuk mengetahui letak, jenis dan kapasitas material berbahaya di SPBU dan SPPBE yang berada hingga jarak $5 \mathrm{~km}$ dari tapak. Batasan ini mengacu pada nilai SDV SPBU dan SPPBE dari pengalaman beberapa negara yang dimuat dalam dokumen IAEA[2]. Dari survei lapangan pada tanggal 13 Juli 2016, hingga jarak 5 km dari tapak RDE didapati instalasi SPBU dan SPPBE seperti di Tabel 1. 


\subsection{Data dan Asumsi}

\subsubsection{Data}

Kapasitas SPBU X, Y dan Z adalah sama sebesar 165.000 liter yang terdiri dari 7 tangki pendam bensin dan solar serta tangki penyimpanan solar jenis Pertamina Dex 5.000 liter di permukaan.

Tabel 1. SPBU dan SPPBE di sekitar tapak RDE

\begin{tabular}{|c|l|l|c|}
\hline Nama & \multicolumn{1}{|c|}{$\begin{array}{c}\text { Jarak } \\
(\mathrm{km})\end{array}$} & \multicolumn{1}{|c|}{ Materi } & \multicolumn{1}{|c|}{ Kapasitas } \\
\hline SPBU X & 1,94 & $\begin{array}{l}\text { Bensin } \\
\text { Dex }\end{array}$ & $\begin{array}{c}165.000 ~ l \\
5.0001\end{array}$ \\
\hline SPBU Y & 3,23 & $\begin{array}{l}\text { Bensin } \\
\text { Dex }\end{array}$ & $\begin{array}{c}165.0001 \\
5.000 ~ 1\end{array}$ \\
\hline SPBU Z & 3,11 & $\begin{array}{l}\text { Bensin } \\
\text { Dex }\end{array}$ & $\begin{array}{c}165.000 ~ 1 \\
5.000 ~ 1\end{array}$ \\
\hline SPPBE A & 2,98 & LPG & $25.000 \mathrm{~kg}$ \\
\hline SPPBE B & 4,10 & LPG & $100.000 \mathrm{~kg}$ \\
\hline
\end{tabular}

Dari pengamatan dilapangan, pada waktu tertentu sebuah truk tangki BBM dengan kapasitas 40.000 liter (berisi bensin dan solar) akan berada di lokasi SPBU untuk melakukan pengisian ulang BBM. Sementara itu kapasitas total SPPBE A dan B masing-masing 25.000 dan $100.000 \mathrm{~kg}$ Liquid Petroleum Gas (LPG) yang masing-masing terbagi dalam 2 tangki. Pada SPPBE inipun pada waktu tertentu terdapat sebuah skid tank LPG/truk tangki LPG dengan kapasitas 15.000 kg untuk melakukan pengisian ulang.

Penelitian ini menggunakan dua set parameter meteorologi (PM) dengan basis data dari stasiun meteorologi Pondok Betung untuk mendapatkan kondisi atmosfer disekitar tapak (Tabel 2). Dua data meteorologi yang digunakan tersebut cukup untuk mewakili kestabilan kondisi atmosfer sekitar tapak dan sesuai dengan masukan yang diperlukan oleh perangkat lunak Areal Locations of Hazardous Atmospheres (ALOHA).

Tabel 2. Data meteorologi stasiun Pondok Betung[8],

\begin{tabular}{lllll}
\multicolumn{5}{c}{$[10]$} \\
\hline PM & $\begin{array}{c}\text { Kecepatan } \\
\text { angin } \\
(\mathrm{m} / \text { detik })\end{array}$ & $\begin{array}{c}\text { Arah } \\
\text { angin }\end{array}$ & $\begin{array}{c}\text { Temperatur } \\
\left({ }^{\circ} \mathrm{C}\right)\end{array}$ & $\begin{array}{c}\text { Kelembaban } \\
(\%)\end{array}$ \\
\cline { 1 - 2 } A & 9,8 & & 34.1 & 74.6 \\
\hline B & 5 & & & \\
\hline
\end{tabular}

Data material berbahaya dan kondisi atmosfir kemudian diolah menggunakan perangkat lunak ALOHA Versi 5.4.5. Juli 2015 dari Badan Perlindungan Lingkungan Amerika Serikat (US EPA).

\subsubsection{Asumsi}

Pada penelitian ini diambil beberapa asumsi terhadap materi berbahaya antara lain bensin dan solar dianggap hanya mengandung $100 \%$ senyawa iso-oktan. Iso-oktan adalah senyawa utama dalam bensin[11]. Asumsi ini diambil karena ALOHA tidak dapat melakukan perhitungan menggunakan dua senyawa. Selain itu asumsi ini dapat diterima karena dilihat dari sifat kimianya Iso-oktan lebih mudah terbakar dibandingkan parafin yang merupakan komponen utama solar. Demikian halnya dengan LPG, diasumsikan sebagai 100\% Butana. Hal ini dikarenakan Butana merupakan komponen utama LPG[12]. Selain itu untuk mendapatkan efek keparahan yang maksimal, maka diasumsikan seluruh material berbahaya bercampur dan berada di atas permukaan tanah, dan kondisi atmosfer yang stabil.

Selain itu, dengan adanya truk tangki BBM di SPBU dan skid tank di SPPBE maka kapasitas maksimum SPBU dan SPPBE selalu terpenuhi yaitu 170.000 liter untuk SPBU X,Y dan Z; $25.000 \mathrm{~kg}$ untuk SPPBE A dan 100.000 $\mathrm{kg}$ untuk SPPBE B. Dengan pertimbangan bahwa keparahan suatu ledakan (yang diakibatkan gelombang kejut) ditentukan oleh kecepatan perambatan ledakan maka untuk mendapatkan efek terparah dari skenario kecelakan ledakan, maka dalam penelitian ini hanya digunakan tipe pemicu ledakan detonasi. Sementara tipe lainnya yaitu deflagrasi tidak digunakan karena perambatan ledakan tipe deflagrasi lebih lambat yaitu 1 meter per-detik dibanding dengan tipe detonasi yang sebesar 2.500 meter per-detik.

\subsection{Seklias ALOHA}

\subsubsection{Penentuan SDV dengan ALOHA}

ALOHA adalah program pemodelan dispersi yang mampu memperkirakan zona ancaman yang terkait dengan rilis kimia berbahaya, termasuk awan uap beracun/mudah terbakar, dan ledakan. Model ini dapat memprediksi hasil dari rilis sesaat dari bahan kimia di udara dan visualisasi dari area terdampak sehingga didapat pemahaman terbaik dari situasi dan luasnya daerah yang 
terkena dampak. Model ini banyak digunakan dalam menganalisis dan melacak rilis bahan kimia menjadi awan uap di udara, awan mudah terbakar dan akhirnya kebakaran dan ledakan[13-16]. Area dampak hasil simulasi kemudian dilihat tingkat keparahan dan cakupan dari kecelakaan ledakan dan kebakaran lalu zona yang mempunyai dampak berbahaya ditetapkan sebagai SDV dari sumber tersebut.

\subsubsection{Zonasi dampak ALOHA}

ALOHA membagi area dampak menjadi tiga lapis zona/zonasi yaitu zona merah, zona jingga dan zona kuning, dengan definisi sesuai dengan skenario kecelakaan.

Skenario ledakan mempunyai efek berbahaya berupa gelombang kejut, yang mampu merusak bangunan maupun mengancam jiwa, mempunyai definisi sebagai berikut:

- zona merah 8,0 psi (mampu merusak bangunan),

- zona jingga 3,5 psi (menyebabkan luka serius), dan

- zona kuning 1,0 psi (meretakkan gelas).

Sedangkan untuk skenario kebakaran, zonasi berupa daerah mudah terbakar yang merupakan area diantara dua nilai presentase konsentrasi campuran udara dan fluida mudah terbakar (awan uap/vapour cloud). Dua nilai tersebut adalah nilai ambang ledakan bawah (lower explosive limit-LEL) dan nilai ambang ledakan atas ( upper explosive limit -UEL). Untuk tujuan konservatif, ALOHA menggunakan $60 \%$ dan $10 \%$ LEL sebagai nilai ambang kebakaran bawah (lower flammability limit) dari awan uap. Sehingga jika daerah mudah terbakar suatu awan uap kontak dengan sumber kebakaran/percikan api, awan uap tesebut akan dengan cepat terbakar. Pembagian zonasi skenario kebakaran disefinisikan sebagai berikut:

- zona merah, LEL

- zona jingga, 60\% LEL

- $\quad$ zona kuning, $10 \%$ LEL.

\section{HASIL DAN PEMBAHASAN}

Hasil simulasi memperlihatkan zonasi bahaya pada area dampak berbeda beda untuk masing-masing skenario kecelakaan dan sumber bahaya.

Hasil penelitian dari skenario kecelakaan ledakan dan bahaya kebakaran pada SPBU X, $\mathrm{Y}$, dan $\mathrm{Z}$ dapat dilihat pada Tabel 3 .

Tabel 3. Hasil Simulasi ALOHA Untuk Sumber SPBU

\begin{tabular}{|c|c|}
\hline & SPBU Y \\
\hline \multirow{4}{*}{ Ledakan } & PM tipe $\mathrm{A}$ \\
\hline & $\begin{array}{l}\text { Jangkauan } 1,8 \mathrm{~km} \text { dari pusat } \\
\text { dengan zonasi sesuai arah angin: } \\
\text { Jarak } 811 \mathrm{~m} \text { (zona merah) } \\
\text { Jarak } 958 \mathrm{~m} \text { (zona jingga) } \\
\text { Jarak } 1,8 \mathrm{~km} \text { (zona kuning) } \\
\end{array}$ \\
\hline & PM tipe B \\
\hline & $\begin{array}{l}\text { Jangkauan } 2 \mathrm{~km} \text { dari pusat SPBU dengan } \\
\text { zonasi sesuai arah angin: } \\
\text { Jarak } 1,1 \mathrm{~km} \text { (zona merah) } \\
\text { Jarak } 1,2 \mathrm{~km} \text { (zona jingga) } \\
\text { Jarak } 2 \mathrm{~km} \text { (zona kuning) }\end{array}$ \\
\hline \multirow{4}{*}{ Kebakaran } & PM tipe A \\
\hline & $\begin{array}{l}\text { Jangkauan 2,1 km dari pusat SPBU } \\
\text { dengan zonasi sesuai arah angin: } \\
\text { - Jarak } 727 \mathrm{~m} \\
\text { (9500 ppm = LEL, zona merah) } \\
\text { - Jarak } 976 \mathrm{~m} \\
\text { ( } 5700 \mathrm{ppm}=60 \% \text { LEL = area kantong } \\
\text { api/mudah terbakar, zona jingga) } \\
\text { - Jarak : } 2,1 \mathrm{~km} \\
\text { (950 ppm = 10\% LEL, zona kuning) }\end{array}$ \\
\hline & PM tipe B \\
\hline & $\begin{array}{l}\text { Jangkauan } 2,2 \mathrm{~km} \text { dari pusat } \mathrm{SPBU} \\
\text { dengan zonasi sesuai arah angin: } \\
\text { - Jarak } 955 \mathrm{~m} \text { (zona merah) } \\
\text { - Jarak 1,2km (zona jingga) } \\
\text { - Jarak 2.2 km(zona kuning) }\end{array}$ \\
\hline
\end{tabular}

Dari Tabel 3 dan Gambar 1, zona bahaya untuk masing-masing skenario kecelakaan SPBU terbagi menjadi tiga lapisan. Namun sesuai dengan definisi SDV maka nilai jarak yang dipakai sebagai SDV hanya sampai zona warna jingga yang mana pada zona tersebut masih memberikan efek kerusakan baik pada properti maupun keselamatan manusia.

Untuk skenario kecelakaan ledakan SPBU berkapasitas 170.000 liter mempunyai SDV sejauh $958 \mathrm{~m}$ untuk PM tipe A dan 1200 $\mathrm{m}$ untuk PM tipe B diukur dari pusat sumber ledakan. Sementara zona kuning tidak diikutkan karena pada zona ini tidak menimbulkan bahaya baik pada property maupun jiwa. Sedangkan zona bahaya untuk kebakaran terdapat pada daerah kantong api yang mempunyai konsentrasi Lower Explosive Limit (LEL) hingga 60\% LEL yang merupakan jumlah dimana volume bahan bakar yang sangat mudah terbakar atau meledak bila kondisi-kondisi segitiga api terpenuhi. Sehingga untuk skenario kecelakaan 
kebakaran SPBU berkapasitas 170.000 liter mempunyai SDV sejauh 1200 m baik untuk PM tipe A maupun PM tipe B diukur dari pusat kebocoran/tumpahan maksimal BBM.
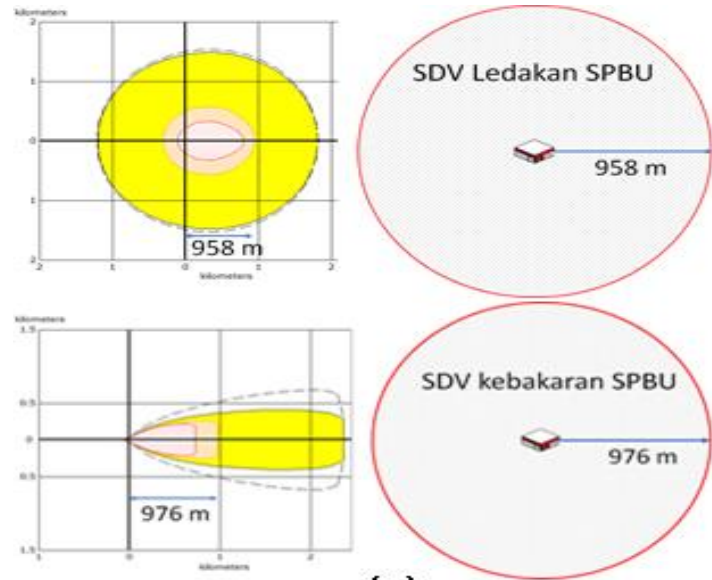

(a)

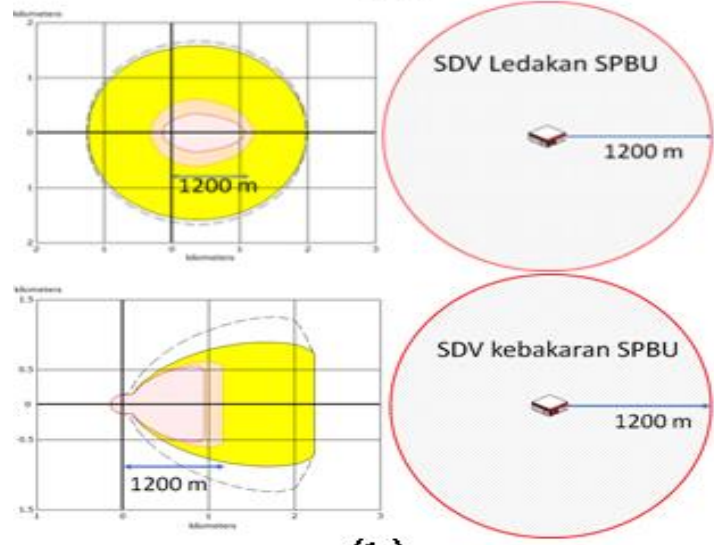

(b)

Gambar 1. Zonasi Bahaya dan SDV Untuk Skenario Kecelakaan Ledakan Dan Kebakaran SPBU, (a) PM Tipe A dan (b) PM Tipe B.

Hasil simulasi pada Tabel 4 yang divisualisaikan pada Gambar 2, dan Gambar 3 dapat diketahui bahwa SDV untuk skenario ledakan SPPBE A berkapasita $25.000 \mathrm{~kg}$ adalah 430 m pada PM tipe A dan 570 m pada PM tipe B sedangkan SPPBE B berkapasitas $100.000 \mathrm{~kg}$ adalah $872 \mathrm{~m}$ pada PM tipe A dan 1100 m pada tipe B. Selain itu didapat juga SDV untuk skenario kecelakaan kebakaran dimana untuk SPPBE A adalah $445 \mathrm{~m}$ pada PM tipe A dan 565 m pada PM tipe B, sedangkan untuk SPPBE B adalah 913 m pada PM tipe A dan 1100 m pada PM tipe B.

Skenario kecelakaan ledakan dan kebakaran untuk SPBU yang disimulasikan ALOHA menunjukkan hasil yang sama pada kedua kondisi atmosfer karena kapasitas isooktana dalam ketiga SPBU tersebut sama. Sementara itu kecelakaan ledakan dan kebakaran untuk SPPBE menunjukkan nilai yang berbeda. Hal ini dikarenakan kapasitas Butana dari SPPBE A dan SPPBE B berbeda. Dengan kapasitas penyimpanan empat kali lebih besar dari SPPBE A, SPPBE B mempunyai SDV dua kali lebih jauh dari SPPBE A baik untuk skenario kecelakaan ledakan maupun kebakaran dalam segala kondisi atmosfer yang dikaji.

Tabel 4. Hasil Simulasi ALOHA untuk Sumber SPPBE

\begin{tabular}{|c|c|c|}
\hline & SPPBE A & SPPBE B \\
\hline \multirow{4}{*}{ Ledakan } & \multicolumn{2}{|c|}{ PM tipe $A$} \\
\hline & $\begin{array}{l}\text { Jangkauan } 873 \mathrm{~m} \\
\text { dari pusat } \\
\text {-Jarak } 368 \mathrm{~m} \\
\text { (zona merah) } \\
\text {-Jarak } 430 \mathrm{~m} \\
\text { (zona jingga) } \\
\text {-Jarak } 873 \mathrm{~m} \\
\text { (zona kuning) }\end{array}$ & $\begin{array}{l}\text { Jangkauan } 1,7 \mathrm{~km} \\
\text { dari pusat } \\
\text {-Jarak } 758 \mathrm{~m} \\
\text { (zona merah) } \\
\text { - Jarak } 872 \mathrm{~m} \\
\text { (zona jingga) } \\
\text {-Jarak } 1,7 \mathrm{~km} \\
\text { (zona kuning) }\end{array}$ \\
\hline & \multicolumn{2}{|c|}{ PM tipe B } \\
\hline & $\begin{array}{l}\text { Jangkauan } 1,1 \mathrm{~km} \\
\text { dari pusat } \\
\text {-Jarak } 479 \mathrm{~m} \\
\text { (zona merah) } \\
\text {-Jarak } 573 \mathrm{~m} \\
\text { (zona jingga) } \\
\text {-Jarak 1,1 km } \\
\text { (zona kuning) }\end{array}$ & $\begin{array}{l}\text { Jangkauan } 1,9 \mathrm{~km} \\
\text { dari pusat } \\
\text { - Jarak } 970 \mathrm{~m} \\
\text { (zona merah) } \\
\text { - Jarak } 1,1 \mathrm{~km} \\
\text { (zona jingga) } \\
\text { - Jarak } 1,9 \mathrm{~km} \\
\text { (zona kuning) }\end{array}$ \\
\hline \multirow{4}{*}{ Kebakaran } & \multicolumn{2}{|c|}{ PM tipe $\mathrm{A}$} \\
\hline & $\begin{array}{l}\text { Jangkauan } 1,4 \mathrm{~km} \\
\text { dari pusat: } \\
\text {-Jarak } 317 \mathrm{~m} \\
(16000 \mathrm{ppm}=\mathrm{LEL}) \\
\text {-Jarak } 445 \mathrm{~m} \\
(9600 \mathrm{ppm}=60 \% \\
\text { LEL = area } \\
\text { kantong api/mudah } \\
\text { terbakar) } \\
\text {-Jarak 1,4 km } \\
(1600 \mathrm{ppm}=10 \% \\
\text { LEL) }\end{array}$ & $\begin{array}{l}\text { Jangkauan 2,4 km } \\
\text { dari pusat } \\
\text {-Jarak } 656 \mathrm{~m} \\
(16000 \mathrm{ppm}= \\
\text { LEL) } \\
\text {-Jarak } 913 \mathrm{~m} \\
(9600 \mathrm{ppm}=60 \% \\
\text { LEL = area } \\
\text { kantong } \\
\text { api/mudah } \\
\text { terbakar) } \\
\text {-Jarak 2,4 } \mathrm{km} \\
\text { (1500 ppm = 10\% } \\
\text { LEL) }\end{array}$ \\
\hline & \multicolumn{2}{|c|}{ PM tipe B } \\
\hline & $\begin{array}{l}\text { Jangkauan } 1,4 \mathrm{~km} \\
\text { dari pusat: } \\
\text {-Jarak } 416 \mathrm{~m} \\
\text { (zona merah) } \\
\text {-Jarak } 565 \mathrm{~m} \\
\text { (zona jingga) } \\
\text {-Jarak 1,4 km } \\
\text { (zona kuning) }\end{array}$ & $\begin{array}{l}\text { Jangkauan } 2,2 \mathrm{~km} \\
\text { dari pusat } \\
\text {-Jarak } 861 \mathrm{~m} \\
\text { (zona merah) } \\
\text { - Jarak } 1,1 \mathrm{~km} \\
\text { (zona jingga) } \\
\text { - Jarak 2,2 km } \\
\text { (zona kuning) }\end{array}$ \\
\hline
\end{tabular}

Sedangkan jika dilihat dari dua tipe sumber tidak bergerak yang diteliti yaitu SPBU dan SPPBE dapat dilihat bahwa SPPBE B dengan kapasitas $100.000 \mathrm{~kg}$ butana mempunyai nilai SDV berbeda dengan SPBU (X,Y dan Z) dengan kapasitas 170.000 liter $\sim 117.600 \mathrm{~kg}$ isooktana. Hal ini karena selain 
karena kapasitas yang berbeda tapi juga karena material yang disimpan pada kedua sumber tersebut berbeda. Efek dari perbedaan jenis material yang disimpan nampak pada nilai LEL dan 60\% LEL Tabel 3 dan Tabel 4. Isooktana mempunyai LEL yang lebih rendah yaitu setengah kalinya dibandingkan dengan butana yang berakibat pada lebih jauhnya jangkauan daerah mudah terbakar dari isooktana dibanding dari butana, dalam segala kondisi atmosfer yang dikaji.

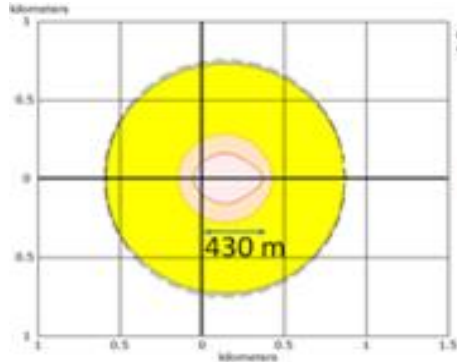

\section{SDV Ledakan SPPBE A}
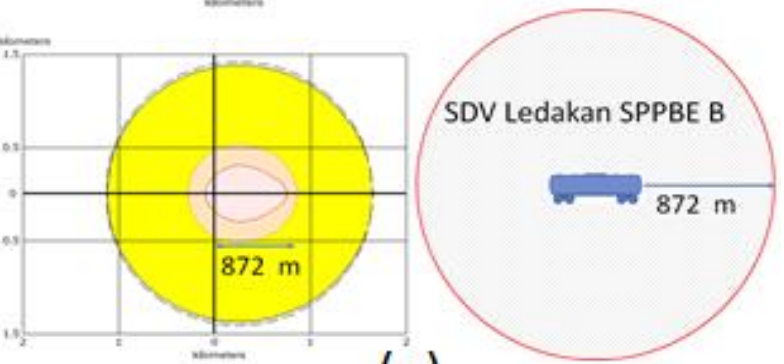

(a)

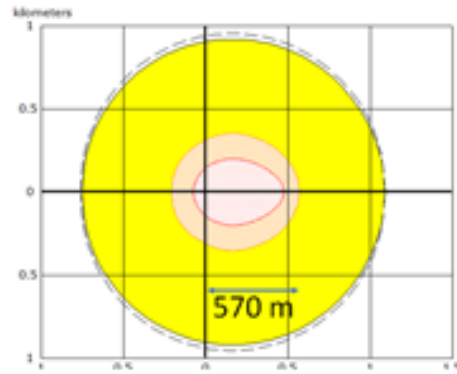

SDV Ledakan SPPBE A

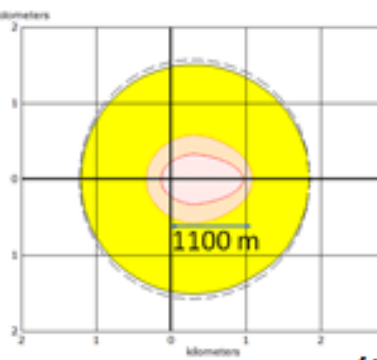

(b)
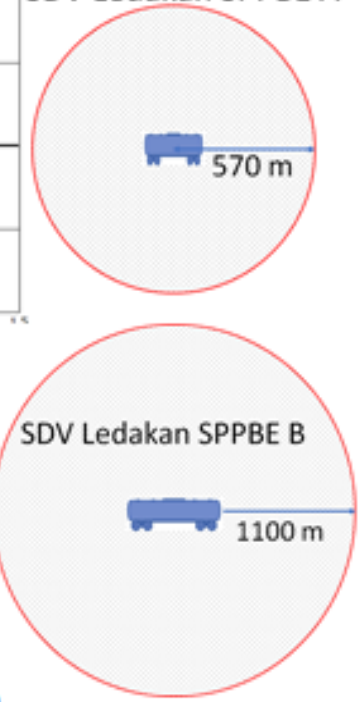

Gambar 2. Zonasi Bahaya Dan SDV Skenario Kecelakaan Ledakan SPPBE, (a) PM tipe A dan (b) PM tipe B.

Dilihat dari skenario kecelakaan yang disimulasikan dapat dilihat bahwa baik SPBU maupun SPPBE, bahwa satu sumber bahaya dapat mempunyai SDV yang berbeda pada kondisi atmosfer tertentu.
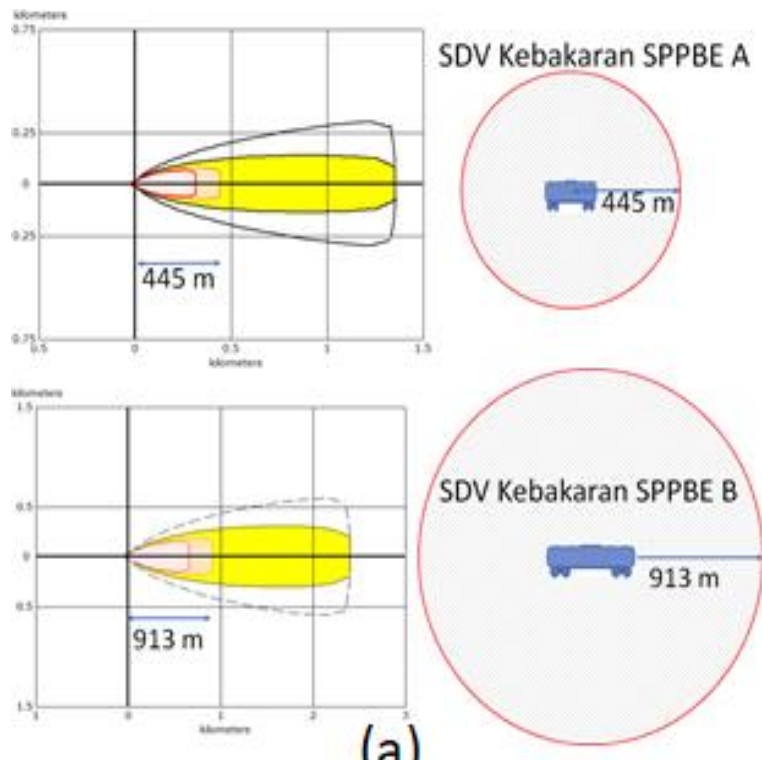

(a)
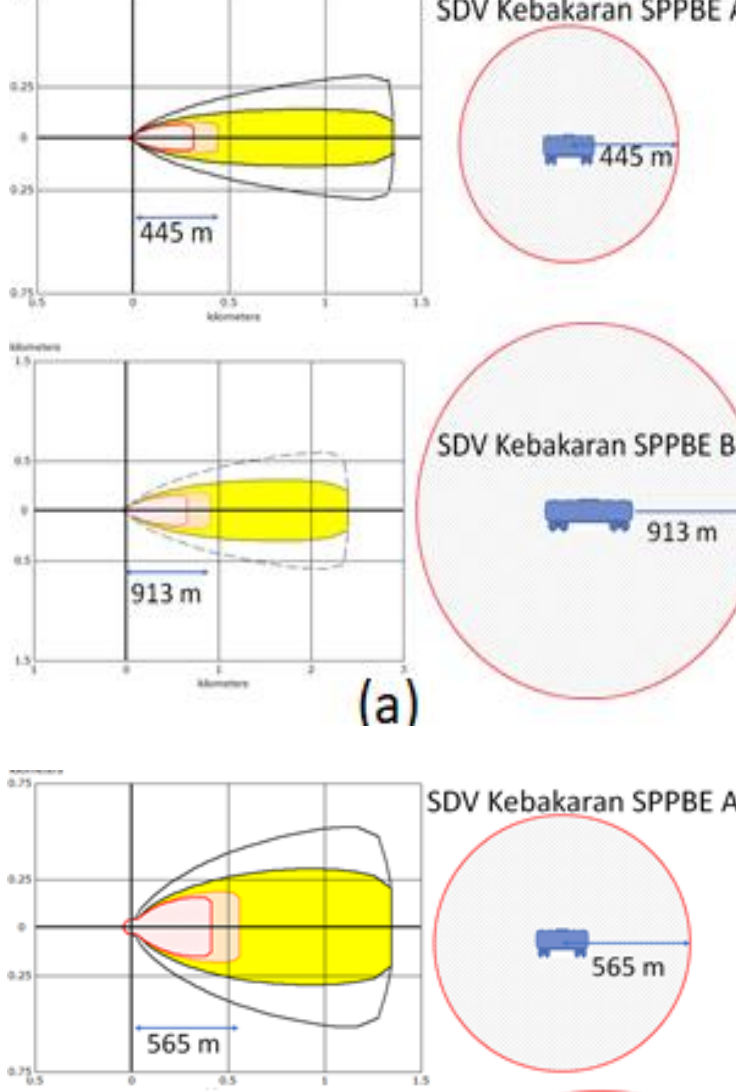

SDV Kebakaran SPPBE A
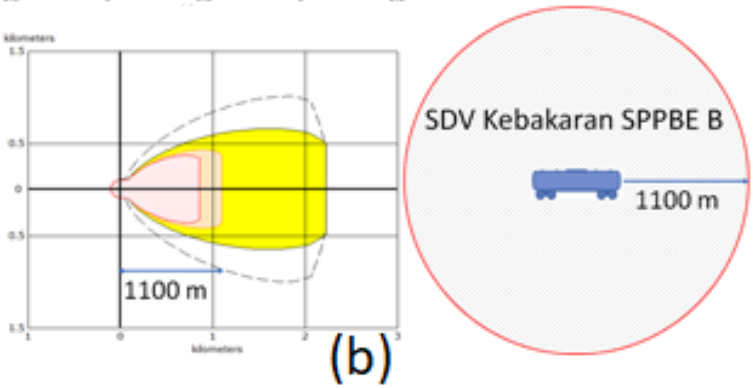

Gambar 3. Zonasi Bahaya Dan SDV Skenario Kecelakaan Kebakaran SPPBE, (a) PM tipe A dan (b) PM tipe B

Dari semua hasil simulasi dapat diketahui bahwa jumlah atau kapasitas serta jenis material berbahaya akan berpengaruh pada nilai SDV. Selain itu, skenario kecelakaan juga akan berpengaruh pada SDV sehingga pada satu sumber bahaya dapat mempunyai lebih dari satu SDV tergantung pada skenario kecelakaan yang diterapkan. Hal lain adalah kondisi meteorolgi daerah tapak juga diketahui akan berpengaruh pada SDV pada sumber yang diteliti.

Selain itu kondisi atmosfer juga berpengaruh pada SDV pada semua jenis sumber dan semua skenario kecelakaan. Dapat diketahui bahwa pada kondisi PM B yang mana kecepatan angin lebih rendah dibanding dengan PM A menghasilkan nilai SDV ratarata 1,2 kali lebih jauh dari SDV pada PM A. Hal ini dapat dipahami karegambarna angin 
akan mendorong material berbahaya untuk tersebar mengikuti arah angin dan konsentrasi dari material tersebut akan terencerkan terus menerus, sehingga memperpendek SDV.

Berbeda dengan studi terdahulu[6-10] khususnya penggunakan nilai SDV $5 \mathrm{~km}$ baik untuk skenario kebakaran SPBU[8] maupun skenario ledakan pada SPPBE[10] maka dari studi ini didapatkan SDV yang spesifik terhadap jenis fluida yang disimpan dan juga skenario kecelakaannya serta kondisi atmosfer di fasilitas yang ditinjau seperti yang ditunjukkan pada Gambar 1, Gambar 2, dan Gambar 3.

\section{KESIMPULAN}

Dari penelitian ini dapat diketahui bahwa SDV sangat tergantung dari jenis, maupun kapasitas material berbahaya, skenario kecelakaan serta kondisi atmosfer pada sumber bahaya. Dengan menerapkan karakteristika sumber, skenario kecelakaan yang ada dan kondis atmosfer maka untuk satu jenis sumber bisa memiliki lebih dari satu SDV.

Pada studi kasus skenario kebakaran dan ledakan pada SPBU dan SPPBE di sekitar tapak RDE didapatkan SDV untuk skenario kecelakaan kebakaran dan ledakan SPBU berkapasitas 170.000 liter pada parameter meteorologi A adalah berturut-turut 976 meter dan 958 meter sedang pada parameter meteorologi B adalah sama yaitu 1.200 meter.

Sedangkan SDV untuk skenario kecelakaan kebakaran dan ledakan SPPBE berkapasitas $25.000 \mathrm{~kg}$ pada parameter meteorologi A adalah berturut-turut 445 meter dan 430 meter, sedangkan pada parameter meteorologi B adalah berturut-turut 565 meter dan 570 meter. Sementara itu, SDV untuk skenario kecelakaan kebakaran dan ledakan SPPBE berkapasitas $100.000 \mathrm{~kg}$ pada parameter meteorologi A adalah berturutturut 913 meter dan 872 meter, sedang pada parameter meteorologi B adalah sama yaitu 1.100 meter.

\section{UCAPAN TERIMA KASIH}

Terima kasih kepada Pusat Kajian Sistem Energi Nuklir yang telah yang telah mendukung dalam penyempuranaan tulisan ini.

\section{DAFTAR ACUAN}

[1]. A. R. Mcbirney, L. Serva, M. Guerra, and C. B. Connor, "Volcanic and seismic hazards at a proposed nuclear power site in central Java," $J$. Volcanol. Geotherm. Res., vol. 123, pp. 11-30, 2003.

[2]. IAEA, "Safety Guide No. NS-G-3.1:External Human Induced Events in Site Evaluation for Nuclear Power Plants," Vienna, 2002.

[3]. B. Wibowo, K. Anzhar, I. Hamzah, and K. Bansyah, "Kajian Awal Bahaya Vulkanik Pada Tapak PLTN Bangka," Rekayasa Teknol. Ind. dan Inf. Sekol. Tinggi Teknol. Nas., 2013.

[4]. A. C. M. Volentik, C. B. Connor, L. J. Connor, and C. Bonadonna, "Aspects of volcanic hazards assessment for the Bataan nuclear power plant, Luzon Peninsula, Philippines," in Connor C., Chapman N., Connor L. Volcanic and Tectonic Hazard Assessment for Nuclear Facilities, 2009, pp. 257-287.

[5]. J. Yarianto, SBS; Hamzah, Imam; Mellawati, "Kajian Keberadaan Bandara Dan Koridornya Dalam Evaluasi Tapak PLTN Muria,” in Prosiding Seminar Nasional Pengembangan energi Nuklir II, 2009, pp. 69-78.

[6]. J. Mellawati, Y. S. B. Susilo, and H. Suntoko, "Sumber Potensial Bahaya Eksternal Akibat Kegiatan Manusia Pada Survei Tapak PLTN,” J. Pengemb. Energi Nukl., vol. 12, no. 1, 2010.

[7]. S. Mellawati, June; Fepriadi; Yarianto, "Identifikasi Sumber Kejadian Akibat Kegiatan Manusia Pada Pra-Survei Tapak PLTN," in Prosiding Seminar Nasional Pengembangan Energi Nuklir IV, 2011, 2011, pp. 49-61.

[8]. D. Mellawati, June. Priambodo, "Evaluasi Potensi Bahaya Kebakaran Dari Sumber Tidak Bergerak (SPBU) Aspek Kejadian Akibat Kegiatan Manusia," in Seminar Nasional XXIII, Kimia Kimia dalam industri dan lingkungan., 2015.

[9]. J. Mellawati and S. Alimah, "The Potential Hazards of Human Activity Around The Nuclear Plant Site: Case Study Of Nuclear Plant Site At Puspiptek, Serpong," in Enhancing Quality of Life Through Human Well Being And Environmental Sustainability In Social Science, 2017, p. 42.

[10]. S. Alimah, D. Priambodo, and J. Mellawati, "Analisis Potensi Bahaya Ledakan SPPBE di Sekitar Calon Tapak RDE,” Maj. IIm. Pengkaj. Ind., vol. 11 No. 1, pp. 23-30, Apr. 2017.

[11]. ESDM, Keputusan Direktur Jenderal Minyak dan Gas Bumi No. 3674K/24/DJM/2006 tentang Standar dan Mutu (Spesifikasi) Bahan Bakar Minyak Jenis Bensin yang Di Pasarkan di Dalam Negeri. Republik Indonesia, 2006, p. Lampiran IIII.

[12]. L. Rosmayati, "Hydrocarbon Composition and Physical-Chemical Properties Assessment of LPG for Household," Publ. Pap. Oil Gas, vol. 46, no. 2, pp. 69-77, 2012.

[13]. D. of E. (DOE), "Defense Nuclear Facilities Safety Board Recommendation 2002-1 Software Quality Assurance Improvement Plan Commitment 4.2.1.3: Software Quality Assurance Improvement Plan: ALOHA Gap Analysis Final Report,” New York, 2004

[14]. S. M. Toufiqur Rahman, M. T. Salim, and S. R. 
Syeda, "Facility layout optimization of an ammonia plant based on risk and economic analysis," in Procedia Engineering, 2014, vol. 90, pp. 760-765.

[15]. H. Zhu, Z. Mao, Q. Wang, and J. Sun, "The influences of key factors on the consequences following the natural gas leakage from pipeline," in Procedia Engineering, 2013, vol. 62.

[16]. H. Shao and G. Duan, "Risk quantitative calculation and ALOHA simulation on the leakage accident of natural gas power plant," in Procedia Engineering, 2012, vol. 45, pp. 352-359. 